third and was lucky for I spent my first six months on a hospital ship going as far as Salonica and being torpedoed off the Devon coast on the way home. The last six months I spent in France and came out after the Armistice to find my partners exhausted after coping with the epidemic of black flu.

The NHI. I was much interested in the paper cutting you sent me about the riots. On the whole an accurate account with some embellishments. It was a most unpleasant time. The coming of the NHI must be a very small beer to you who have been under the (1948) Health Act, but it stirred up the medical profession as never before. Never before had so many GPs become acquainted with each other. Meetings galore, some full of sound and fury, and some very amusing. I remember one at Cambridge: a proposed clause in the Bill was read out which stated that there would be special remunerations for GPs carrying out services which entailed great difficulties and even hardship . . . "such as" a wag remarked "swimming across a lake to a confinement with the forceps in your mouth!' I after often thought what fools we were to stand out: for the NHI was really a good thing. It did away with charges and badly paid parish appointments.

Charges for adults ..........4/- per head per annum.

Charges for juveniles .........2/-per head per annum.

$$
\text { Yours Sincerely }
$$

M F Tylor.

Note: MFT died 1969 aged 94 (born 1875, qualified Oxford and St Georges 1903: Wisbech 1903-19, Dartmouth 1919-35, then retired).

Doctors in any practice can usually think of some unusual case which merits recording elsewhere than their own private diary. Some 25 years ago I was on duty one weekend when I was called urgently to an accident on a council estate several miles away. It was 11 on a Sunday morning. Church bells were summoning their parishioners to Matins. As I sped on my way the siren came to life at the fire station. I thought of it only as an interesting coincidence, but as I neared my destination a somewhat irate fire chief hooted me out of the way. We ended up at different ends of the village square which was otherwise deserted. Clearly we seemed to be on different errands. I entered a house unknown to me and found an obese lady bending over her washing machine. Hanging free from the top of her oversize dress and unprotected by any "bra" was a large and pendulous breast, the nipple of which was tightly caught in the gearing.

It is of course well known that accidents did happen with the old fashioned washing machines: fingers could get trapped in the rollers, as could human hair, but wisely the manufacturers catered for these mishaps with quick release buttons so that the agony was only temporary. What the makers could not have foreseen was the use of the machine after the gears and cogs which spin the rollers had been exposed by the removal of the metal casing normally hiding them from view. In this instance the lady's nipple-now purple, swollen, and oily - had been caught in the works as she bent unwisely over the greasy machinery.

I was alone with this poor soul, who mercifully could see the funny side of things. The machine had stopped and, so long as the patient kept still and was prepared to bend forward with her nose just above the water line, all was well, but attempts to look up or move very naturally caused agonising pain. My mind flashed back to textbooks on emergencies for the worried casualty officer. What would Hamilton Bailey or Pye have done in the circumstances? I had no such helpful guidance.

At this point the chief fire officer discovered the correct address and entered the room. He was followed by the local constable, the district nurse, a still more senior police officer, six more firemen, and a nearby relative who had heard of the crisis. Outside was the fire engine, a fire tender, police cars, and now an ambulance. I felt that the room was getting decidedly stuffy. We decided on inspection that the gearing would part company with the rollers (this with a last howl of protest). We strapped breast and gearing (still tightly gripping the tender nipple in its teeth), to the chest wall. The patient was carefully transported to the local hospital. The surgeon in turn evidently thought this was not his field of action and promptly called in Bert, the electrician, to institute therapy. Deftly with varying sizes of screwdriver, the cogs were disassembled, the nipple released. When seen the next day the delighted lady announced, "I am so pleased for I have been asking Bert to mend my Hotpoint for ages and now he will come tomorrow."

\title{
Dermatology in Edinburgh: The first 100 years
}

\author{
J A SAVIN
}

Here we sit, smug and snug in our glistening new seminar room. One hundred people, all working in dermatology, 15 of them from our own department, are soaking up the massed wisdom of the country's seven professors of dermatology-all this to celebrate the 100 th anniversary of the skin department at the Royal Infirmary of Edinburgh. The professors sparkle brightly, but after a few hours images from the past begin to drift across my mind ...

In the foreground I see another professor, the late $\mathrm{G} \mathrm{H}$ Percival (figure 1), proud to have been the first holder of the first established university chair of dermatology in Britain. Pen in hand, he is fully able in his 80 s to dash off the 357 pages of his pungent and scholarly treatise on "The History of Dermatology in Edinburgh" (unpublished observations), so inadequately condensed to a few sentences here. Behind him stands the bristling Dr Allan Jamieson (figure 2), triumphant at last in his "small dark room" at the infirmary. Beyond Jamieson the line of dermatology stretches back to Robert Willan, graduating from Edinburgh University in 1780. Further away still the early infirmary, founded in 1729 and

Department of Dermatology, the Royal Infirmary, Edinburgh EH3 9YW

J A SAVIN, MD, FRCP, consultant dermatologist royal since 1736 , is shrouded in mist. It seems incredible that such a hospital could have limped on for a century and a half without a skin department.

But in those days the general physicians and surgeons here were keen on dermatology. How they squealed when Dr Jamieson, fresh from Hebra's clinic in Vienna, kept pressing for a room in which to see skin patients. Skin cases were not numerous, they said, and the existing consultants were well able to deal with them. And perhaps they had a case.

\section{Joys of lumping and splitting}

Who can fault a system that delivered such a fine series of doctors, many interested in dermatology, into key positions in London? Edinburgh had perfected the methods of clinical training started in Leiden, and its teaching during the second half of the eighteenth century was among the best in Britain. Richard Bright and Thomas Addison, both Edinburgh graduates, had flirted with dermatology but their main achievements were to lie in other fields. Robert Willan and Thomas Bateman, however, went on to become the two most important dermatologists of their time. Robert Willan, one of the first to bring order to the chaos of skin diseases, had learnt the joys of lumping and splitting from William 
Cullen, professor of the institutes of medicine, master nosologist and follower of Linnaeus, whose writings were also much admired by the French dermatologist Alibert. ${ }^{1}$ Indeed, that "cradle of British dermatology," the Carey Street dispensary in London, was between 1783 and 1791 staffed largely by graduates from the Edinburgh medical school.

In Edinburgh the torch of dermatology was carried onward through the nineteenth century by a group of interested general physicians and surgeons led by John Hughes Bennet, a professor

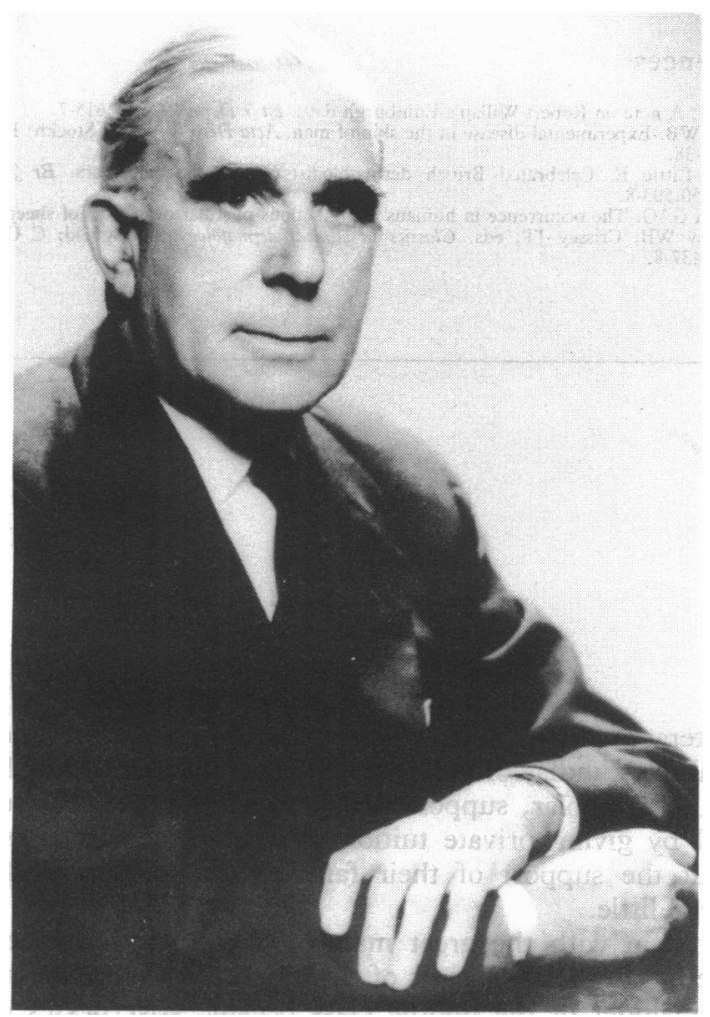

FIG 1-The late Professor G H Percival, first holder of the Grant chair of dermatology in the University of Edinburgh.

in the faculty of medicine. In the 1840 s he was hot on the trail of Schönlein and Gruby in pursuit of the recently discovered "parasitic vegetable structures," which cause favus and ringworm, beating both to become the first to reproduce favus experimentally in man. ${ }^{2} \mathrm{He}$ wrote widely on dermatology and in 1850 was given two wards in the infirmary solely for the care of skin conditions. Thomas Laycock, professor of the practice of physic, also wrote a pamphlet on skin diseases and studied the contagiousness of boils The two of them shared, rather uneasily, the running of the skin wards and were later joined by Sir Douglas McLagan. Edinburgh surgeons were also interested in dermatology, notably Joseph Bell, whose inspired guesses from the state of the skin and nails- "You know my methods, Watson"-made Conan Doyle turn him into Sherlock Holmes.

Against this background it is easy to see why dermatology was hard to establish as a separate discipline in Edinburgh. Professor Percival lingers lovingly over the paranoid scufflings that scotched the first attempt to establish a dispensary for diseases of the skin by Dr Edward Duffin in 1824. Duffin backed off to London and ophthalmology. A second attempt in 1838 foundered after a few years, as did a third in 1869. Later a fourth Edinburgh dispensary for skin diseases did useful work between 1890 and 1966 .

Life was no easier at the infirmary itself. Dr Allan Jamieson had both drive and ability and later was to become president of the Royal College of Physicians of Edinburgh, but he needed luck as well to force his way in-and here leg eczema enters the story for the first time. He did well with the eczema of one of the hospital managers, Daniel Rutherford Haldane, who was able to jockey Jamieson's request for outpatient facilities through a split board of management. In 1884 Jamieson's reward was a share in a small dark room that he could use on Saturday mornings. Seven years later, after a titanic struggle with the clinical professors, he added a few beds to his empire. In 1892 he was joined by the influential Dr Norman Walker (later to be Sir Norman and president of the General Medical Council), who had studied under Kaposi and Unna.

These two master tacticians more than held their own in the jostling throng of new specialists in other disciplines, and together built up "the most fully equipped skin department in a general hospital in Great Britain."3 Soon the Saturday morning clinics were teaching "the greatest number of English speaking students that have anywhere assembled to learn dermatology." Many came from abroad, and Edinburgh skin textbooks went round the world, Walker's running to 13 editions. In 1899 dermatology became compulsory for the medical students, who had to spend more time on it then than they do now.

\section{Need for a new department}

Jamieson and Walker were followed by Frederick Gardiner (appointed physician in 1912), an expert radiologist as well as a dermatologist, Robert Cranston Low (1924), one of the first to

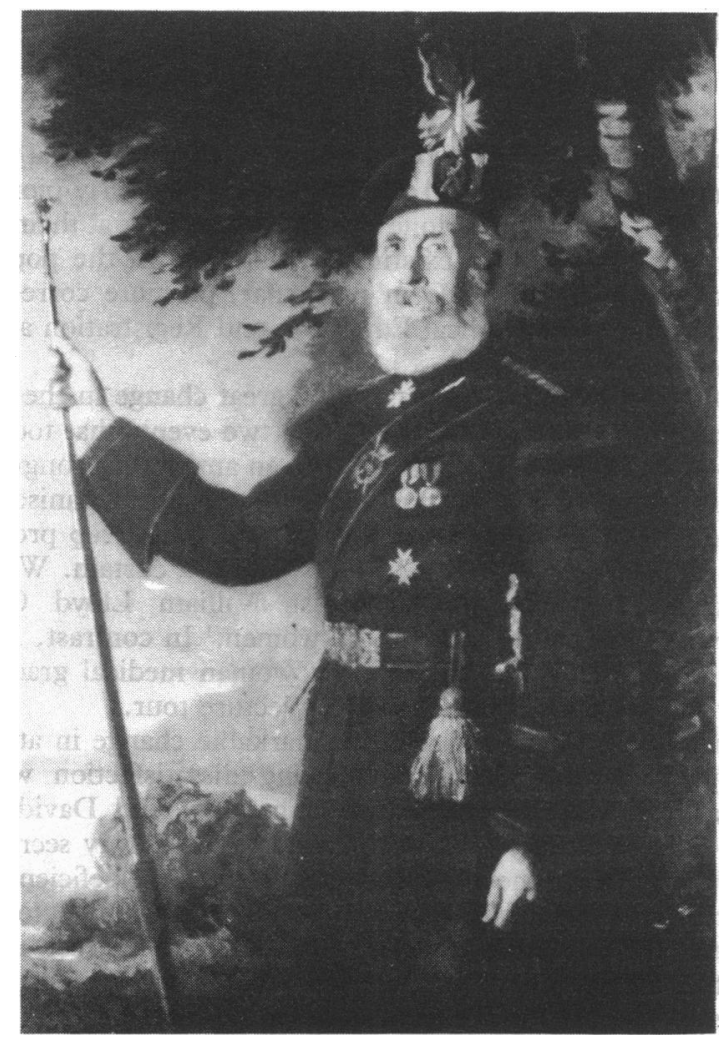

FIG 2-Portrait of Dr Allan Jamieson in the uniform of the Royal Company of Archers, which hangs in the hall of the Royal College of Physicians of Edinburgh.

look into the immunology of contact dermatitis, and Robert Aitken (1933). Their clinics grew remorselessly; patients spilled over into the corridors; and at last the rest of the medical staff had to admit that the hospital's most pressing need was for a new skin department. A five storey ferroconcrete pavilion shot up, combining the 1930s' look with a faint hint of the Scottish country house. But the venereologists took the lion's share of it, aggravating their offence by sending a stream of arsenical eruptions up to the dermatologists packed into the top two floors. 
Dr George Percival joined the consultant staff when the new building was opened in 1936. Trained in Paris, Lausanne, and Zürich, he knew as well as Dr Jamieson how to deal with leg eczema. Sir Robert Grant, the head of a family already lavishly generous to the University of Edinburgh, was aware of the damage that skin disease could do to his employees, and was unhappy when he developed eczema of his legs after several days of strenuous shooting in wet weather. Pleased with Percival's cure he gave $£ 80000$ to found a chair of dermatology in Edinburgh, and in 1946 Dr Percival became its first holder. New staff brought new strength to the department.

Dr G A Grant Peterkin, whose first description in 1937 of orf in man has become a modern classic, ${ }^{4}$ and Dr Patrick Hannay, became consultants. A whole floor was reclaimed from the venereologists. Professor P J Hare succeeded Professor Percival in 1966. All helped to build up a modern department and to man peripheral clinics covering Fife and the Borders. In 1982 we moved to our new outpatient department, its many light rooms in striking contrast to Dr Jamieson's small dark one.
But enough of the past: dermatology is still a young subject. One half of all the consultant dermatologists ever appointed to the Royal Infirmary are here today in the seminar room. The professorial fireworks are spluttering to an end and soon we will be joining those who trained here, but who now work elsewhere, in a feast to celebrate their return to Edinburgh and to fill us with energy for the future. With things as they are now we need another slice of luck: even the fatted calf will be searched for traces of eczema.

\section{References}

Hare PJ. A note on Robert Willan's Edinburgh days. Br f Derm 1973;88;615-7.

Shelley WB. Experimental disease in the skin of man. Acta Derm Venereol (Stockh) 1982; suppl 108:1-38.

Graham-Little E. Celebrated British dermatologists of the last 50 years. $\mathrm{Br} \mathcal{F}$ Dermatol 1938;50:503-8.

Peterkin GAG. The occurrence in humans of contagious pustular dermatitis of sheep (orf). In: 1953:437-8. Crissey JT, eds. Classics in clinical dermatology. Springfield: C C Thomas,

\title{
Women and the GMC
}

\author{
JEAN M SCOTT
}

In considering the struggle by women for General Medical Council registration, I shall not deal with the lives of the early pioneers in any detail. That has been done already. I shall look at their actions in the light of attitudes existing at that time in the population generally and in the GMC in particular, or more correctly the General Council of Medical Education and Registration as it was then known.

The mid-nineteenth century saw a great change in the lives of women, best illustrated by comparing two events that took place within a short period of time. In 1840 an antislavery congress was held in London and to the confusion of the organisers four American women delegates arrived. In order to keep proprieties right, the women were made to sit behind a curtain. When the distinguished American abolitionist William Lloyd Garrison arrived, he insisted on joining the women. ${ }^{1}$ In contrast, 20 years later, Elizabeth Blackwell, the first woman medical graduate in America, was invited to Britain on a lecture tour.

What had brought about this remarkable change in attitudes? Firstly, there was already a growing dissatisfaction with the standard of education of women. The Reverend David Laing, vicar of Holy Trinity, Kentish Town, was honorary secretary of the Governesses' Benevolent Institute. He saw the deficiencies and along with Miss Murray, maid of honour to Queen Victoria, was responsible for founding Queen's College, Harley Street, in $1848 .^{2}$ Other churchmen gave support, including the Reverend Charles Kingsley. Sophia Jex Blake was one of the early pupils.

Women themselves were becoming more active. The Langham Place group formed by the Leigh Smiths and Bessie Raynor Parkes was responsible for the appearance of the English Woman's Fournal in $1858 .{ }^{3}$ This was an important step giving them a voice to influence public opinion. In parliament, too, women found support from men like Cowper Temple and Russell Gurney and in

^Based on a presidential address given to the Council of the Medical Women's Federation, 5 May 1984.

Pitlochry, Perthshire

JEAN M SCOTT, MD, FRCPATH, retired consultant pathologist

Correspondence to: Tiriach, Clunie Bridge Road, Pitlochry, Perthshire PH16 5JX. the literary world John Ruskin, Lord Tennyson, and more particularly Findlay of the Scotsman and Professor David Masson, the Milton scholar, supported the women's cause. Medical men helped by giving private tuition or holding special classes, but without the support of their families the women would have achieved little.

To begin with the great mass of Victorian womanhood was indifferent to the arguments of the rebels. The fortunate married, the remainder of the middle class became governesses or companions, while the working classes scrubbed and scoured. Perhaps if Sophia Jex Blake had been treated more fairly in Edinburgh public opinion might not have been roused to the same extent, for echoes reached parliament and were even heard in the GMC.

Before the Medical Act 1858, which set up the GMC, anyone could practise medicine. The 1841 Census showed that though 34000 were doing so less than 11000 were qualified. The first move to improve the position came from Charles Hastings, who in 1832 founded his Provincial Association of Physicians and Surgeons, out of which the British Medical Association was born. Then, as Sir David Campbell said, "the battle of the Bills began," and according to Sir Norman Walker, "A lot was going on behind the scenes, the laymen against the universities. . . I have found no secret documents and all those concerned are now dead . . . but the Medical Act was, in a sense, an expression of the influence and status of the chartered bodies." He described the first council as a "timid experiment" with powers of control "too small." It met on 23 November 1858, with 17 representatives of the licensing bodies and six nominated by the Privy Council. Sir Robert Christison was among the latter. The council elected Sir Benjamin Brodie from outwith the council as president. Christison became chairman of the select committee on education and treasurer of the Scottish branch council. He was obviously in a position of power.

\section{Examiners resigned}

The early minutes show clearly the effective way that the council set about improving standards by controlling registration and education. Inspectors were appointed in the first year and by 1860 registration of medical students was under way. Problems 